\title{
Dominika Dziurosz-Serafinowicz
}

\section{W podróży samopoznania}

\section{Monika Walczak, Wgląd i poznanie. Epistemologia Bernarda J. F. Lonergana, Wydawnictwo KUL, Lublin 2012, ss. 477}

Nie ulega wątpliwości, że Wgląd $i$ poznanie Moniki Walczak jest owocem zarówno długoletniej pracy translatorskiej, jak i wnikliwej anali-

Dominika Dziurosz-Serafinowicz - ur. w 1984, absolwentka Wydziału Filozoficznego PAT z 2007 roku. Doktorantka UPJPII od 2012. zy filozoficznej niełatwego dzieła, jakim jest Insight. A Study of Human Understanding Bernarda Lonergana (1904-1984). Wydaje się, że książka Walczak jest doskonałym preludium do długo oczekiwanego tłumaczenia głównego dzieła tego kanadyjskiego filozofa ${ }^{1}$. Wgląd i poznanie składa się z dziewięciu rozdziałów i stanowi nie tylko rzetelne źródło wiadomości o tym, czym jest wgląd w rozumieniu Lonergana, ale jest również szerokim omówieniem jego filozofii poznania, która niewątpliwie stanowi fundament całej jego filozofii.

W pierwszym rozdziale czytelnik ma szansę zapoznać się z intelektualną biografią tego oryginalnego filozofa, wskazującą na jego klasyczne, filozoficzne i teologiczne studia (doktorat z teologii uzyskał w 1946 roku), życie zakonnika-jezuity i wykładowcy związanego z ośrodkami akademickimi w Bostonie, Rzymie, Toronto, Londynie i Montrealu.

Rozdział drugi jest ciekawą propozycją osadzenia filozofii Lonergana w którejś z tradycji filozoficznych, wskazując na podobieństwa

1 Choć z ideami myśli lonerganowskiej można się zapoznać za pośrednictwem częściowych tłumaczeń i analiz jego komentatorów, to sam tekst Insight pozostaje w trakcie tłumaczenia, którego podjęli się A. Bronk i sama autorka. 
z myślą tomistyczną, fenomenologiczną, hermeneutyczną, egzystencjalną i scjentystyczną, jednocześnie uświadamiając czytelnikowi, jak bardzo myśl Lonerganowska wymyka się wszelkim próbom typologizacji i stanowi nowatorską propozycję filozoficzną.

Trzeci rozdział, poświęcony filozofii poznania, jest próbą ustaleń terminologicznych i rozstrzygnięć filozoficznych dotyczących trzech dyscyplin epistemologicznych. Przyjrzyjmy się mu nieco bliżej, albowiem zdaje się on kluczowy dla innych zagadnień. Znajdziemy tutaj wyjaśnienie różnic między teorią poznania, epistemologią i metafizyką.

Teoria poznania (cognitional theory) zajmuje się poznaniem (knowing) oraz podmiotowymi warunkami poznania, próbując odpowiedzieć na pytanie „Co czynię, kiedy poznaję?”. Wydaje się, że ta dziedzina jest według autorki najważniejsza, albowiem zawiera główną dyrektywę całej filozofii Lonerganowskiej: dyrektywę samorozwoju, samopoznania i samoprzyswojenia (self-appropriation). Właśnie tutaj rozpoczyna się „podróż samoodkrycia”, podróż po samoświadomości dążącej do samoafirmacji. Tutaj również dochodzi do uformowania koncepcji trójpoziomowej struktury poznania. Autorka wskazuje na empiryczny i praktyczny charakter teorii poznania, jednak odróżniając ją od tego, o czym mowa w psychologii poznawczej.

Epistemologia zajmuje się warunkami podmiotowo-przedmiotowymi, chcąc odpowiedzieć na pytanie „Dlaczego działalność ta jest poznaniem?”. Kluczowym zagadnieniem dla epistemologii jest obiektywność i prawdziwość poznania. Odwołuje się ona do klasycznej definicji prawdy, albowiem: „Z poznaniem mamy do czynienia wtedy, gdy rzeczy mają się tak, jak głoszą sądy realizowane przez podmiot”2. Jednakże samemu Lonerganowi nie chodzi jedynie o wytworzenie sądu prawdziwego - a więc przekonania prawdziwego i uprawomocnionego - lecz o usprawnianie samego procesu poznawczego, który, kiedy jest genetycznie poprawny, w sposób „naturalny” prowadzi do sądów prawdziwych. Ponadto Lonergan ukuwa przykazania transcendentalne 
(transcendental precepts): „bądź uważny, bądź inteligentny, bądź rozumny” i, nawiązujące do tradycji intelektualizmu etycznego, „bądź odpowiedzialny", podkreślające wartościująco-normatywny charakter epistemologii. W zdrowej, i polecanej, postawie poznawczej, dołącza się jeszcze „bezstronne, bezinteresowne, czyste, nieograniczone pragnienie poznania", mogące się wyrazić w maksymie wskazywanej przez D. Oko: „bądź otwarty”. A więc postawa otwartości będąca „badającym i krytycznym duchem człowieka" stanowi zarówno cel, jak i podłoże obiektywnego poznania. Ważny wydaje się tutaj również moralny wymiar poznania, albowiem człowiek pozostając zakłamany i niewierny swojemu poznaniu, nie może dojść do prawdy. W ramach epistemologii ciekawe jest także podkreślanie przez Lonergana samodzielności i indywidualności filozofa, który ma za zadanie wypracować swoje własne stanowisko filozoficzne (epistemologia pozytywna) i być gotowy do ustosunkowywania się do innych stanowisk (epistemologia negatywna), których pluralizm jest wynikiem „polimorfizmu ludzkiej świadomości”. Wydaje się, że jest to propozycja niezwykle trafna w świecie współczesnego zubożenia filozoficznego, które zdaje się polegać jedynie na komentowaniu lub podpisywaniu się pod czyimiś tezami, nie zaś na budowaniu własnego systemu filozoficznego. Odnosząc się krytycznie do samego ujęcia Lonerganowskiego, wydaje się, że dopuszcza on jedyny poprawny system metafizyczny, warunkowany jego teorią poznania. Wypływa to z tego, iż uznaje on pierwotność przestrzeni epistemicznej wobec metafizycznej. Inne stanowiska metafizyczne będą mogły być natomiast jedynie zaburzonymi metafizykami, które jako nadbudowane na odmiennych wzorcach świadomości i nieuznające Lonerganowskiej struktury poznania, należałoby uznać za błędne. Wydaje się, że z takiej perspektywy stanowisko Lonergana jest fundamentalistyczne, gdyż w świetle jego filozofii poznania, cokolwiek nie odnajdzie struktury poznania jest w nieprawdzie i domaga się „nawrócenia”: „Nie rozumieją sensu Lonergana metafizyki, epistemologii i teorii poznania tak długo, jak długo nie

D. Oko, Łaska $i$ wolność. Łaska w Biblii, nauczaniu Kościoła i teologii współczesnej, Kraków 1997, s. 259. 
dokonają podstawowego odwrócenia swego stanowiska filozoficznego co do rzeczywistości, obiektywności i siebie jako podmiotu"'.

Metafizyka jest dziedziną zajmującą się przedmiotowymi warunkami poznania, próbując odpowiedzieć na pytanie „Co poznaję, kiedy poznaje??". Metafizyka, choć nakierowana jest na przedmiot i przez to wydaje się samodzielna, stanowi część filozofii poznania i jest zależna od zarówno epistemologii, jak i teorii poznania. Metafizyka jest wynikiem poznawczego rozwoju jednostkowego podmiotu. Zostają wyróżnione trzy postaci metafizyki: ukryta (latent), problematyczna (problematic) i uwyraźniona (explicit). Pierwsza to „immanentna i działająca struktura ludzkiego poznania”, druga to „dzieje ludzkich wysiłków uczynienia z metafizyki ukrytej metafizyki uwyraźnionej”, trzecia w definicji Lonergana "jest pojęciem, afirmacją i wdrożeniem (implementation) integralnej, heurystycznej struktury proporcjonalnego bytu"”.

Rozdział czwarty jest dokładnym przedstawieniem dynamicznej struktury poznania z poziomami kolejno: doświadczenia, rozumienia (inteligencji) i sądzenia (refleksji), które za punkt wyjścia przyjmują dane zmysłowe i dane świadomości, czyli tzw. empiryczne reziduum. Teoria poznania u Lonergana przeciwstawia się analitycznej tradycji podkreślającej jedynie wartość wiedzy jako sądu. Walczak wskazuje nam, że i u Lonergana sąd jest celem poznania, jednak droga do niego jest równie ważna, jak on sam (co wskazywałoby na pewne powiązania z myślą dialektyczną). W filozofii poznania nie tylko ważna jest wiedza (knowledge), ale sposób, w jaki do niej dochodzimy (knowing). Walczak wielokrotnie podkreśla ów czynnościowy charakter poznania. Ważne wydaje się również rozróżnienie wiedzy wygenerowanej immanentnie i zawierzenia. Ta pierwsza jest wiedzą osobistą, do której dochodzimy samodzielnie $\mathrm{w}$ trzypoziomowym procesie poznawania. Ta druga jest wynikiem osobistego zaufania autorytetowi i wiedzy przez niego przekazanej:

M. Walczak, Wgląd..., dz. cyt., s. 115.

Tamże, s. 118.

Tamże.

Tamże, s. 119. 
„Natomiast typowy proces zawierzenia przebiega od wiedzy w jednym umyśle do zawierzenia tej samej prawdy w innym umyśle”8.

Rozdział piąty jest przedstawieniem koncepcji obiektywności u Lonergana oraz połączonego z nią stanowiska realizmu krytycznego. Tzw. problem mostu zostaje zniesiony i uznany za pozorny poprzez odrzucenie perspektywy, która chce po jednej stronie umieścić poznającego (podmiot), po drugiej zaś to, co poznawane (przedmiot). Przyjmując tę niepoprawną perspektywę, podmiot z góry skazuje się na niepowodzenie w rozwiązaniu problemu krytycznego, albowiem odgradza to, co w sposób naturalny jest połączone. To, co poznawane, zawsze idzie w parze z poznawaniem, które jest dokonywane przez podmiot poznający. Lonergan odwołuje się tutaj do analizy i opisu immanentnych czynności poznawczych podmiotu, a w szczególności do ich świadomego i intencjonalnego charakteru (w spuściźnie Husserlowskiej), które jako takie już posiadają odniesienie przedmiotowe. Rzetelność i poprawność przeprowadzanego procesu poznawczego jest jednocześnie gwarancją przedmiotowości poznania, albowiem, jak mówi Lonerganowska maksyma: „Obiektywność jest owocem autentycznej subiektywności”.

Rozdział szósty „Natura wglądu i typy wglądu” jest próbą zarówno odróżnienia pojęcia wglądu (insight) od pojęcia intuicji (intuition, visio, Anschauung, epagogé) oraz wstępnym podaniem ogólnych cech wglądu. Przy tej okazji Walczak zarysowuje historię rozwoju pojęcia intuicji, wyróżniając jej rozumienie jako typ poznania, wiedzy i dyspozycji poznawczej. Przedstawione zostaje rozumienie intuicji u Platona, Kartezjusza, Kanta, Husserla, Bergsona, Rorty'ego i wielu, wielu innych. Wyłuskane zostają również jej cechy charakterystyczne. Sam wgląd zaś zdaje się najbliższy temu, co starożytni rozumieli pod pojęciem epagogé, rozumianej jako wynik dłuższego i skomplikowanego procesu poznawczego, niemal procesu pedagogicznego (choć tutaj bardziej samo-pedagogizującego), a zdecydowanie odgradza się od rozumienia go

\footnotetext{
Tamże, s. 170.

"Genuine objectivity is the fruit of authentic subjectivity" (B. J. F. Lonergan, Method in Theology, Toronto 1990, s. 292).
} 
jako Anschauung. Wszelkie wglądy są wyzwalające $\mathrm{z}$ napięcia badania, nieoczekiwane i nagłe. Ponadto są funkcją warunków wewnętrznych, oscylują między konkretem a abstrakcją i przechodzą w „habitualną strukturę umysłu"10. W tym rozdziale znajdziemy również rozbudowaną typologię wglądów, wyróżniającą wglądy z poziomu inteligencji, refleksji, praktyczne i zdroworozsądkowe.

Rozdział siódmy jest próbą udzielenia odpowiedzi na pytanie, jak dochodzi do powstania wglądu - jakie są tego warunki. Z punktu widzenia współczesnej filozofii nauki najbardziej interesującą cechą wglądu jest jego wartość odkrywcza, jego umiejętności rozwiązywania problemów dotąd nierozwiązanych, potrzebujących elementu twórczego. Samo pojęcie insight nie jest źródłowo pojęciem filozoficznym ${ }^{11}$, lecz psychologicznym, wywodzącym się z psychologii postaci. To, w jaki sposób dochodzimy do wglądu, wydawało się sprawą psychologiczną - pewnych dyspozycji, talentów, geniuszu człowieka, nie zaś filozoficznego ukonstytuowania podmiotu poznawczego ${ }^{12}$. Jednakże bodaj już od czasów starożytnych „to, w jaki sposób rozpoznaje się prawdę, kiedy dociera się do tego, co wcześniej było nieznane"13, było przedmiotem zainteresowania filozoficznego. Lonergan twierdzi, że człowiek oprócz wrodzonych władz poznawczych (doświadczenia, rozumienia i sądzenia) posiada również dyspozycje nabyte, wyrażające się w „habitualnej strukturze umysłu", która umożliwia widzenie spraw jako proste i oczywiste $\mathrm{w}$ procesie dokonywania kolejnych wglądów. W ramach genezy wglądu ponownie podkreślona jest ważność pragnienia poznania (będącego "habitualną orientacją umysłu”). Jest to nic innego, jak Arystotelesowskie „Omnes homines natura scire desiderant” ${ }^{14}$, u Lonergana,

$10 \quad$ M. Walczak, Wgląd..., dz. cyt., s. 239.

11 Nie znajdziemy jego opracowania w dziesięciotomowej Encyclopedia of Philosophy pod redakcją D. M. Borcherta z 2006 roku ani dziesięciotomowej Routledge Encyclopedia of Philosophy pod redakcją E. Craiga z roku 1998.

12 Walczak wyodrębnia różne rozumienia wglądu w psychologii poznawczej: „Gestalt”, „Nic specjalnego", „Puzzle-problem” i „Genialne umysły”. Zob. M. Walczak, Wglad..., dz. cyt., s. $266-275$.

13 Lonergan podejmuje tutaj znany problem Platona. Zob. tamże, s. 353.

14 Arystoteles, Metaphysica, księga A, $980^{\mathrm{a}} 1$. 
nawiązującego do Corethowskiej filozofii pytania, przyjmujące postać podmiotu pytającego (Der Mensch ist der Fragende) ${ }^{15}$, który w cyrkularności i kumulatywności poznania dokonuje kolejnych wglądów poprzez stawianie kolejnych pytań, które osadzają się zarówno w tym, co już jakoś znane i tym, co jeszcze nieznane a jedynie domyślane (antycypowane, clue). W ramach genezy rozważona zostaje rola danych, wyobrażeń i abstrakcji w dokonywaniu wglądów. Wiele uwagi poświęcono interesującemu zagadnieniu ucieczki od rozumienia oraz zjawisku przeoczenia, należących do błędów poznawczych oraz sposobowi ich korekty i uzdrowienia podmiotu poznającego.

Rozdział ósmy prezentuje powiązanie intuicji i wglądu poprzez zwrócenie uwagi na ich przedmiot. W historii intuicja była kojarzona z poznawaniem: tego, co ogólne/proste (Platon, Proklos, Boecjusz, św. Tomasz, Kartezjusz, Leibniz, Locke), co jednostkowe/indywidualizujące (Duns Szkot, Platon, Ockham, Spinoza, Croce), materialne i zmysłowe (nowożytny empiryzm), co duchowe/idealne (Platon, Plotyn, aksjologia fenomenologiczna, intuicjonizm etyczny), własnych przeżyć i aktów (Kartezjusz, empiryści brytyjscy, Russel), jaźni/absolutu (Plotyn, św. Augustyn, św. Bonawentura, Gioberti, Fichte, Schelling). Wgląd natomiast posiada inny przedmiot jako punkt wyjścia (dane, wyobrażenie), a inny jako punkt dojścia. W ramach tego drugiego inną sytuację mamy w przypadku wglądów bezpośrednich, odwrotnych i zreflektowanych. Przedmiot tych pierwszych odznacza się inteligibilnością, ogólnością i indywidualnością, aspektywnością (abstrahowalnością tego, co istotne), modalnością, jednością i całościowością. Te drugie jeno kwestionują "przedmiot jako materiał do tworzenia hipotez"16. Te trzecie (wglądy zreflektowane) nawiązują do tego, co znane pod pojęciem illative sense - a więc zmysłu wnioskowania.

Rozdział dziewiąty i zarazem ostatni, noszący tytuł „Epistemiczne własności i funkcje wglądu” ponownie odnosi się zarówno do intuicji, jak i wglądu. Ta pierwsza w tradycji filozoficznej była uznawana za 
odznaczającą się bezpośredniością/naocznością/oczywistością oraz nieomylnością/pewnością/niepowiątpiewalnością, będąc przez to krytykowana za brak intersubiektywności (Schopenhauer, Hartmann), zapośredniczenie (Peirce), omylność i możliwość błędów (Popper, Albert), a nawet brak poznawczego charakteru (Schlick). Dla Lonergana wgląd stanowi niewyzbywalny i najważniejszy element procesu poznawczego. Spełnia funkcję unifikującą, porządkującą i konstrukcyjną. W ramach komentarza chciałabym przyjrzeć się dwóm pytaniom, szczególnie mnie intrygującymi, otóż: „ [...] dlaczego i jak te same dane doświadczenia dopuszczają powstawanie na ich podstawie różnych wglądów oraz dlaczego na bazie określonych danych powstaje taki, a nie inny wgląd" ${ }^{17}$. Odpowiedzią na oba te pytania miałaby być różnorodność procesów poznawczych podmiotów, które znajdują się niejako na różnych poziomach rozwoju poznawczego. Różnorodność i wielość teorii, hipotez, konceptualizacji, schematyzacji i punktów widzenia zdaje się być całkowicie uwarunkowana indywidualizacją i historycznością (zindywidualizowaną historią) podmiotu poznającego. Czy jednak nie należałoby, zgodnie z ideą tego, że nasze poprawne poznanie jest zawsze przedmiotowe (odnosi się do tego, co realne i obiektywne), zaś podmiot poznaje, wyprowadzić wniosku, że i przedmiot jest różnorodny i wieloaspektowy? Że skoro następuje wzbogacanie naszego obrazu świata poprzez dokonywanie coraz to lepszych i więcej obejmujących wglądów, to znaczy, że i to, co tu-teraz-tam-na-zewnątrz-rzeczywiste odznacza się niezwykłym bogactwem i głębią? Że skoro mamy zachować realizm, to należy wyprowadzić z naszej różnorodności teorii wniosek, że i realność jest niezwykle głęboka, skoro pozwala na generowanie tylu wglądów i idących za nimi sądów? Wydaje się, że wiele, jeśli nie większość, koncepcji mówiących o obiektywności zakłada statyczny obraz zarówno podmiotu, jak i przedmiotu. Lonergan wyraźnie zrywa ze statycznym rozumieniem podmiotu, jednak zdaje się nie wyprowadzać dynamicznej struktury świata ${ }^{18}$. Czynnikiem twórczym

17 Tamże, s. 354.

18 Należy zaznaczyć, że Lonergan mówi o emergentnym prawdopodobieństwie, co wskazywałoby na pewną świadomość dynamicznego charakteru rzeczywistości. 
i dynamicznym może być nie tylko sam podmiot, ale i przedmiot, który nie jest w swej naturze jednoznaczny, prosty, stały i ciągle kierujący się jedną regułą/prawem/zasadą, a właśnie także polimorficzny. Ów przedmiot nie narzuca jednej interpretacji o sobie, lecz właśnie ich wielość. Nie tylko dlatego nie ma "nagich faktów”, bo każdy człowiek jest inaczej poznawczo „uposażony” czy „nastawiony”, ale również dlatego, że to, co tu-teraz-tam-na-zewnątrz jest samo z siebie „wielobarwne”. Oglądamy przedmiot przez pryzmat różnych struktur poznawczych, ale $-\mathrm{z}$ drugiej strony - sam przedmiot, jak strużka światła białego, jest źródłem tak wielu różnych barw. „Te same dane doświadczenia” nie są tak naprawdę i nigdy „tymi samymi danymi doświadczenia” nie tylko przez to, że my je różnie organizujemy, ale również dlatego, że one nigdy nie są prostymi, wyizolowanymi impresjami. Cecha wielointerpretowalności świata może być konsekwencją braku ostatecznej i jednej struktury rzeczywistości, a przenikania się w samej rzeczy niezwykłej wielości różnych struktur. Poszukiwanie więc jednego przebiegu zdarzeń, jednej - właściwej interpretacji zdarzeń - będzie z samej natury rzeczy błędem kategorycznym. Wydaje się, że w świetle propozycji Lonergana nasza sfera „twardych faktów” winna ulec „elastyzacji” i dynamizacji, że nasze poszukiwanie prawdy toczy się tak wieloma ścieżkami i drogami, albowiem nie tylko my popełniamy błędy poznawcze i jesteśmy w ciągłym procesie samokorekty, ale również świat jest źródłem wielu różnych prawd.

Podsumowując należy zaznaczyć, że książka Wgląd i poznanie jest nie tylko bardzo kompetentnym opracowaniem zagadnienia Lonerganowskiego wglądu, ale stanowi także prezentację wielu debat filozoficznych (m.in. realizm-antyrealizm, intuicjonizm-racjonalizm, obiektywizmsubiektywizm), w których uwzględniony jest głos nie tylko samego Lonergana i jego interpretatorów (A. Bronk, D. Oko, J. Herbut, B. Cronin, J. F. Flanagan, P. Byrne, F. E. Crowe, H. A. Meynell, M. Vertin), ale także autorów innych tradycji filozoficznych, w tym zarówno polskich (R. Ingarden, K. Ajdukiewicz, S. Kamiński, S. Judycki, K. Twardowski, M. A. Krąpiec, E. Nęcka, T. Czeżowski), jak i zagranicznych (A. Plantinga, A. I. Goldman, E. Sosa, P. Moser, J. E. Davidson, H. G. Gadamer, J. Maritain). 
Pewnym brakiem jednak może być to, że książka nie posiada ani wyraźnie zarysowanej tezy filozoficznej, której zamierza bronić, ani precyzyjnie określonej metody filozofowania. Ponadto nie jest ona ani bezstronnym i czystym zreferowaniem poglądów Lonergana, ani też ich pełną krytyczną analizą. Chociaż autorka podejmuje próbę poddania koncepcji wglądu Lonergana krytyce metodami analitycznymi, to nie jest to próba zupełnie udana. Wydaje się, że wymogi filozofii analitycznej są bardziej restrykcyjne, a rasowy analityk nie przebrnąłby przez pierwsze kilka rozdziałów Insight, uznając je za mało precyzyjne, nienaukowe i samosprzeczne. Oczywiście monografia zawiera ową propozycję interpretacji pojęcia wglądu poprzez odniesienie jej do intuicji, jednak jest to tylko próba zrozumienia wglądu przez pryzmat tejże kategorii, nie zaś krytyczne ustosunkowanie się do całej koncepcji Lonergana. W ramach krytycznych uwag należy podkreślić również to, że książka posiada pewne błędy językowe i literówki, które w takiej publikacji już nie powinny wydarzać się tak często.

Pomimo jednak owych braków, które w dużej mierze wydają się wypływać z problematyczności i ambiwalentności poglądów filozoficznych samego Lonergana, Wgląd i poznanie jest pozycją niezwykle wartościową, będącą świadectwem niezwykłego trudu interpretacyjnego. Ponadto na jej końcu znajdziemy rozbudowaną bibliografię, kalendarium życia i prac Lonergana, glosarium, indeksy, co wraz z przejrzyście uporządkowaną treścią sprawia, że książka nabiera charakteru niemal podręcznikowego i staje się przystępna nie tylko dla znawców myśli Lonerganowskiej, ale również jej młodych adeptów. 